\author{
Dawid Kamiński \\ Wydział Politologii \\ Uniwersytet Marii Curie-Skłodowskiej w Lublinie
}

\title{
Wspieranie małych i średnich przedsiębiorstw przez wladze gminne w woj. świętokrzyskim - wyniki badań ankietowych
}

Począwszy od 1989 r. obserwuje się w Polsce wzmożony rozwój małych i średnich przedsiębiorstw. Efektem tego procesu jest całkowita zmiana struktury wielkościowej podmiotów gospodarczych. Według GUS, w 2006 r. w kraju funkcjonowało ogółem 1,7 mln przedsiębiorstw, w tym małe i średnie firmy stanowiły 99,8\%. W strukturze zatrudnienia firmy tej grupy wielkości obejmowały $70,8 \%$ ogółu pracujących. Dla porównania, w państwach Unii Europejskiej małe i średnie przedsiębiorstwa stanowią również $99,8 \%$ ogólnej liczby podmiotów gospodarczych i zatrudniają 71,2\% ogółu pracujących (The European Observatory for SMEs Sixth Report, 2005).

Duże znaczenie małych i średnich firm w państwach Unii Europejskiej, w tym w Polsce, jest obecnie niekwestionowane, ze względu na cechy i funkcje, jakie MŚP pełnią w gospodarce narodowej. Działania produkcyjne na małą skalę, bez względu na to, jak liczne, są prawie zawsze mniej szkodliwe dla środowiska przyrodniczego niż działania na wielką skalę, ponieważ ich zakres jest zawsze mniejszy (Schumacher 1981). Drobne firmy odznaczają się elastycznością działania, mobilnością, dużą odpornością na zjawiska kryzysowe. Stwarzają dodatkowe miejsca pracy, doskonale sprawdzają się $\mathrm{w}$ kooperacji $\mathrm{z}$ wielkimi zakładami. Ponadto, jak wynika z badań, małe i średnie przedsiębiorstwa wykazują dużą zdolność do wchodzenia na nowe rynki zbytu, nawiązywania kontaktów z partnerami zagranicznymi, transferu technologii i kapitału, racjonalizacji zatrudnienia i płac (Kamińska 2006).

Rozwój małych i średnich przedsiębiorstw w Polsce, traktowany jako wyraz przekształceń w gospodarce, jest ukierunkowany na kształtowanie się nowego systemu gospodarczego, cechującego się zwiększaniem udziału przemysłu konsumpcyjnego i usług, dostosowaniem produkcji do potrzeb rynkowych, demonopolizacją produkcji i wzrostem konkurencji (Dolata 2006). Wykazuje on jednak duże regionalne zróżnicowanie, co jest dowodem na to, że nie wszystkie jednostki przestrzenne w jednakowym stopniu dostosowały się do nowych zasad gospodarowania. Obok województw o bardzo dużym udziale MŚP w gospodarce (np. wielkopolskie, pomorskie) są województwa (podlaskie, lubelskie, podkarpackie), w których proces rozwoju małych i średnich firm przebiega zdecydowanie wolniej. Jak na tym tle przebiega proces powstawania MŚP w woj. świętokrzyskim?

Celem niniejszej pracy jest - oparta na wynikach badania ankietowego - analiza instrumentów wspierania sektora małych i średnich przedsiębiorstw przez samorządy terytorialne w gminach woj. świętokrzyskiego.

\section{Metody badań}

W pracy wykorzystano dwa rodzaje metod badawczych:

1. Metoda ankietowa

Wzór ankiety pochodzi z Instytutu Badań nad Gospodarką Rynkową. Ankieta była skierowana do władz lokalnych i składała się z siedmiu części. Część pierwsza dotyczyła podstawowych 
danych o gminie (liczba mieszkańców, wydatki budżetu, liczba podmiotów gospodarczych). W części drugiej skoncentrowano się na dochodowych instrumentach wspierania rozwoju MŚP. Pytania dotyczyły wysokości stawek podatkowych oraz ulg i zwolnień podatkowych. W części trzeciej zamieszczono pytania dotyczące instrumentów wydatkowych. Chodziło głównie o planowane i realizowane inwestycje, a także o dofinansowanie lub wspólfinansowanie przez gminy przedsięwzięć związanych ze wspieraniem MŚP. Części czwarta, piąta i szósta dotyczyły szczegółowych rozwiązań w zakresie stosowania instrumentów wydatkowych. Część siódma dotyczyła barier w rozwoju sektora MŚP.

2. Metody graficzne

Wśród metod graficznych szeroko wykorzystano metody kartograficzne, zwłaszcza kartogramy. Umożliwiło to pokazanie prawidłowości przestrzennych w występowaniu analizowanych zjawisk. Metodę tę zastosowano do przedstawienia rozmieszczenia MŚP w gminach woj. świętokrzyskiego oraz do przedstawienia wyników badań. W pracy wykorzystano także wykresy kołowe.

\section{Charakterystyka społeczno-gospodarcza obszaru badań}

Woj. świętokrzyskie powstało w 1999 r. Leży w Polsce południowo-wschodniej i obejmuje 11,7 tys. $\mathrm{km}^{2}$, co stanowi 3,7\% ogólnej powierzchni Polski (pod względem powierzchni znajduje się zatem na dalekim, 15. miejscu). Obszar ten w 2006 r. zamieszkiwało 1291,6 tys. osób, czyli 3,4\% ogółu mieszkańców kraju (13. miejsce). Gęstość zaludnienia wynosiła 109 osób na $\mathrm{km}^{2}$ (średnia dla Polski - 122 osoby na $\mathrm{km}^{2}$ ). W układzie przestrzennym wskaźnik gęstości zaludnienia wahał się od 30 w gminie Fałków do 1890 w Kielcach.

W latach 1999-2006 liczba ludności obniżyła się o 2,4\% na skutek ujemnego przyrostu naturalnego (od $-0,6 \%$ do $-1,7 \%$ ) oraz ujemnego salda migracji (od $-1,6 \%$ o do $-2,0 \%$ ). W układzie przestrzennym wzrost liczby ludności zanotowano jedynie w gminach położonych w bezpośrednim sąsiedztwie dużych miast. Na obszarach peryferyjnych województwa liczba ludności zmalała.

W miastach mieszka 45,7 \% ludności woj. świętokrzyskiego (średnia w kraju - 61,8\%). Sieć miejską tworzy 30 miast, spośród których tylko Kielce są miastem dużym (powyżej 200 tys. mieszkańców). Dwa miasta, Ostrowiec Świętokrzyski i Starachowice, należą do miast średnich (liczba mieszkańców 50-100 tys.), kolejne trzy, Końskie, Sandomierz i Skarżysko-Kamienna, mają po 20-50 tys. mieszkańców. Pozostałe miasta są małymi jednostkami osadniczymi; liczą mniej niż 20 tys. mieszkańców.

W woj. świętokrzyskim jest 2127 wiejskich jednostek osadniczych. Przeciętna liczba mieszkańców we wsi wynosi 330 osób. Strukturę wielkościową wsi zaprezentowano w tab. 1.

Tab. 1. Liczba i wielkość wiejskich jednostek osadniczych w woj. świętokrzyskim

\begin{tabular}{|c|c|c|c|c|c|c|}
\hline \multirow{2}{*}{ Lata } & \multirow{2}{*}{ Liczba wsi } & \multicolumn{5}{|c|}{ Miejscowości o liczbie ludności } \\
\cline { 3 - 7 } & & poniżej 200 & $\mathbf{2 0 0 - 4 9 9}$ & $\mathbf{5 0 0 - 9 9 9}$ & $\mathbf{1 0 0 0 - 2 0 0 0}$ & powyżej 2000 \\
\hline 2002 & 2127 & 856 & 922 & 254 & 86 & 9 \\
\hline
\end{tabular}

Źródło: obliczenia autora na podstawie danych GUS.

W województwie następuje wyraźny proces starzenia się ludności: wskaźnik starości wynosił 17,2\% (w Polsce 13,0\%), a mediana wieku 37,3 lat (w Polsce 36,2). Proces starzenia jest zróżnicowany przestrzennie. Najwyższe wskaźniki starości występują w gminach wiejskich położonych na peryferiach powiatów i województwa. 
Pracujący stanowili 33,3\% ogółu ludności województwa (na 1000 mieszkańców przypadały 333 osoby pracujące). W strukturze zatrudnienia przeważało rolnictwo, skupiające 32,5\% ogółu pracujących. Przemysł i budownictwo łącznie skupiały 23,1\% pracujących, usługi rynkowe $27,6 \%$, a usługi nierynkowe $16,8 \%$. Stopa bezrobocia wynosiła $22,0 \%$ (w Polsce 20\%). PKB na 1 mieszkańca odpowiadało 78,2\% średniej krajowej.

Działalność gospodarcza w województwie jest reprezentowana głównie przez małe i średnie przedsiębiorstwa. W 2006 r. na 1000 mieszkańców przypadało ich 83, a na 1000 mieszkańców w wieku produkcyjnym - 272.

Przyrodnicze warunki rozwoju rolnictwa są bardziej dogodne w części południowej województwa niż w części północnej. Przeważają gleby klas IV i V. Barierą rozwoju rolnictwa jest silne rozdrobienie gospodarstw. Przeciętna wielkość gospodarstwa rolnego wynosi 4,07 ha.

\section{Stan sektora MŚP w woj. świętokrzyskim w 2006 r.}

W 2006 r. w woj. świętokrzyskim było 41697 aktywnych przedsiębiorstw z sektora MŚP, co stanowiło 2,5\% ogólnej liczby aktywnych przedsiębiorstw kraju. W strukturze wielkościowej podmiotów gospodarczych przeważały przedsiębiorstwa najmniejsze - do 9 zatrudnionych. W 2006 r. było ich ponad 40 tys.; stanowiło to $96 \%$ ogólnej liczby aktywnych przedsiębiorstw województwa (ryc. 1 i 2).

Ryc. 1. Struktura wielkościowa aktywnych przedsiębiorstw w woj. świętokrzyskim w 2006 r.

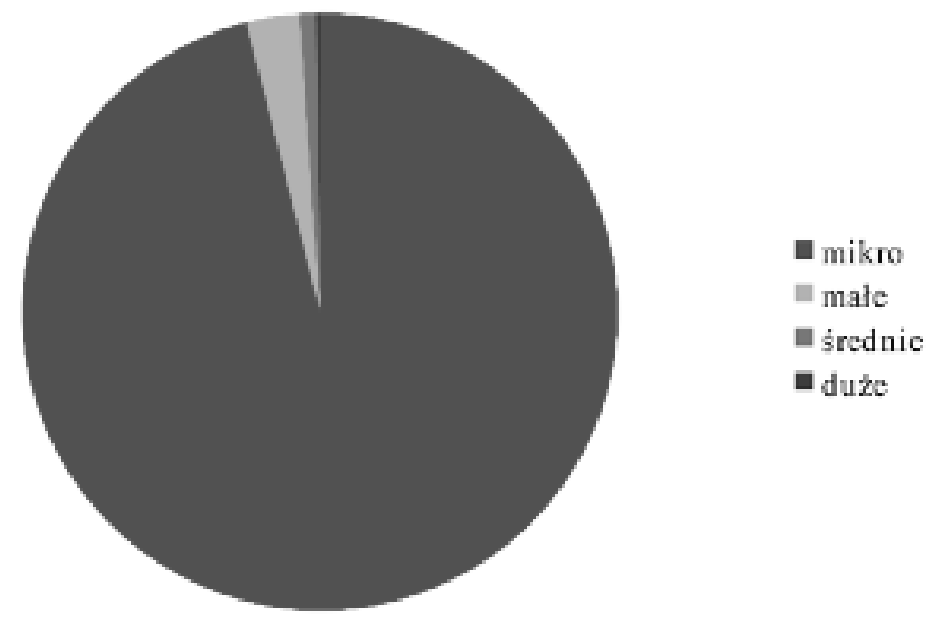

Żródło: opracowanie autora.

Ryc. 2. Struktura pracujących w aktywnych przedsiębiorstwach różnej wielkości w woj. świętokrzyskim w 2006 r.

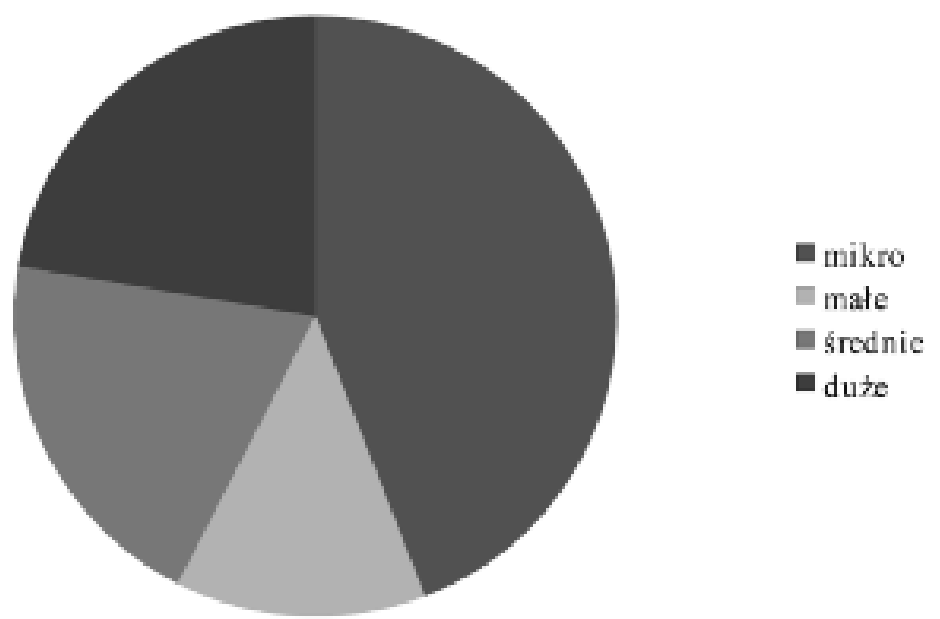

Źródło: opracowanie autora. 
Drugą pozycję zajmowały przedsiębiorstwa małe (2,9\% ogólnej liczby przedsiębiorstw w województwie), a trzecią firmy średnie (0,9\%). Łącznie MŚP stanowiły aż 99,8\% wszystkich przedsiębiorstw na badanym obszarze.

Nieco inaczej przedstawiała się struktura pracujących. Firmy mikro skupiały 44,05\% ogółu pracujących w województwie. Firmy małe stworzyły miejsca pracy dla 13,55\% pracujących, a średnie przedsiębiorstwa dla 20,07\%. Łącznie sektor MŚP obejmował 77,7\% pracujących.

Duże przedsiębiorstwa stanowiły zaledwie $0,2 \%$ ogólnej liczby firm badanego obszaru, ale zatrudniały one $22,33 \%$ pracujących.

\section{Rozmieszczenie małych i średnich przedsiębiorstw w woj. świętokrzyskim}

W woj. świętokrzyskim bardzo atrakcyjne dla lokalizacji MŚP były miasta. Znajdowało się w nich 63,8\% wszystkich firm badanego obszaru, a zamieszkiwało je 45,8\% mieszkańców (tab. 2). Obszary wiejskie skupiały 36,2\% MŚP oraz 54,2\% mieszkańców. W Polsce w miastach znajduje się 73,5\% ogółu małych i średnich firm, a mieszka w nich 61,8\% mieszkańców kraju, na obszarach wiejskich zaś $26,5 \%$ podmiotów tej grupy wielkościowej oraz 38,2\% ludności Polski. Jednak iloraz lokalizacji będący stosunkiem odsetka MŚP do odsetka ludności wskazuje, że miasta woj. świętokrzyskiego odznaczają się większą niż średnio miasta w Polsce atrakcyjnością dla lokalizacji małych i średnich przedsiębiorstw.

Tab. 2. MŚP na obszarach miejskich i wiejskich w woj. świętokrzyskim i w Polsce w 2006 r.

\begin{tabular}{|c|c|c|c|}
\hline \multirow{2}{*}{ Wyszczególnienie } & \multicolumn{2}{|c|}{ Woj. świętokrzyskie } & \multirow{2}{*}{ Iloraz lokalizacji } \\
\cline { 2 - 4 } & \multicolumn{2}{|c|}{ udzial (\%) } & \\
\cline { 2 - 4 } & woj. świętokrzyskie & w ogólnej liczbie MŚP & $\begin{array}{c}\text { w ogólnej } \\
\text { liczbie ludności }\end{array}$ \\
\hline Miasta & 63,8 & 45,8 & 1,40 \\
\hline Wieś & 36,2 & 54,2 & 0,67 \\
\hline Razem & $\mathbf{1 0 0 , 0}$ & $\mathbf{1 0 0 , 0}$ & $\mathbf{x}$ \\
\hline
\end{tabular}

Źródło: opracowanie autora.

Można zatem przyjąć, że obszary miejskie i wiejskie stwarzają różne warunki dla rozwoju MŚP. Ze względu na fakt, że potencjał MŚP w miastach jest nieporównywalnie większy niż na obszarach wiejskich, warunki rozwoju tego sektora w miastach i na wsi woj. świętokrzyskiego zostaną przedstawione oddzielnie.

Poszczególne miasta odznaczały się zróżnicowanym stopniem atrakcyjności dla lokalizacji małych i średnich firm. W strukturze przestrzennej MŚP województwa zdecydowanie przeważały Kielce (ryc. 3), które w 2006 r. skupiał 40,6\% zakładów tej grupy wielkościowej zlokalizowanych w miastach oraz 35,7\% mieszkańców miast. Drugą pozycję zajmowały trzy ośrodki: Ostrowiec Świętokrzyski, Starachowice i Skarżysko-Kamienna. Łącznie na koniec 2006 r. te trzy miasta koncentrowały ponad 27,8 ogólnej liczby MŚP zarejestrowanych w miastach województwa oraz 30,4\% jego mieszkańców.

Zdecydowanie mniej atrakcyjne okazały się Sandomierz i Końskie, które razem obejmowały 8,8\% zakładów oraz 7,9\% mieszkańców. 
Ryc. 3. Rozmieszczenie małych i średnich przedsiębiorstw w miastach woj. świętokrzyskiego w 2006 r.
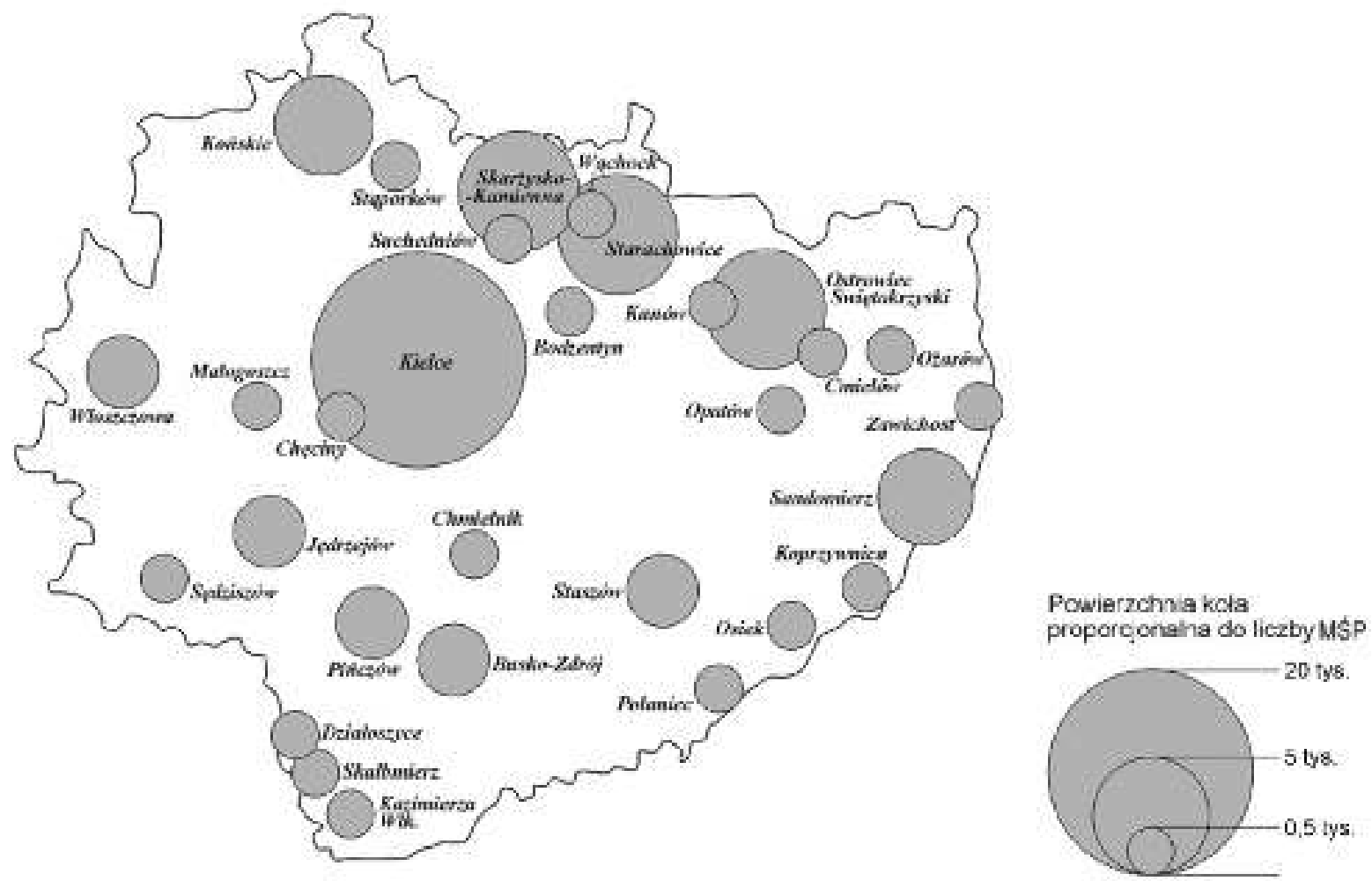

Źródło: opracowania autora.

Można stwierdzić, że poszczególne miasta odznaczały się odmiennymi warunkami rozwoju sektora MŚP, co było związane z wielkością, funkcjami i poziomem rozwoju społeczno-gospodarczego poszczególnych centrów. Najlepsze warunki wystąpiły w Kielcach - wiodącym na tym terenie biegunie wzrostu - które odznaczały się dużym potencjałem społeczno-gospodarczym (Hausner, Kudłacz, Szlachta 1995) i pełniły funkcje usługowo-przemysłowe (Zioło 1994). Jest to miasto wojewódzkie, o lepiej rozwiniętej infrastrukturze niż w pozostałych ośrodkach województwa. W Kielcach działają wyższe uczelnie (dwie państwowe i sześć prywatnych); miasto podłączone jest do sieci TELENEGRO i TELEBANK; w Kielcach znajdują się placówki Krajowego Systemu Usług dla małej przedsiębiorczości, centra informacji, izby gospodarcze, agencja rozwoju regionalnego oraz inne instytucje wspierające biznes (Kamińska 2004).

Gorsze warunki wystąpiły w dużych ośrodkach zlokalizowanych wzdłuż linii kolejowej od Końskich po Ostrowiec Świętokrzyski, stanowiących trzon Staropolskiego Okręgu Przemysłowego. Miasta te pod względem atrakcyjności inwestycyjnej zaliczane są do klas C i D (Swaniewicz, Dziemianowicz 1998). W Starachowicach działa specjalna strefa ekonomiczna; na jej terenie zlokalizowanych zostało 50 firm (Dębski 2002). Czynnikiem pobudzającym powstawanie MŚP była również prywatyzacja zakładów państwowych (np. huty w Ostrowcu Świętokrzyskim). Grupowe zwolnienia, sprzedaż majątku (lub jego części) prywatyzowanych przedsiębiorstw i tendencje do dekoncentracji pionowej stały się motywacją dla ludności lokalnej do zakładania własnych zakładów.

Najgorsze warunki wystąpiły w miastach o niższym poziomie rozwoju społeczno-gospodarczego. Są to najczęściej miasteczka liczące do 10 tys. mieszkańców, położone na peryferiach województwa, z dala od ważnych szlaków komunikacyjnych (Kazimierza Wielka, Skalbmierz, Działoszyce, Osiek) lub w odległości kilku-kilkunastu kilometrów od głównego ośrodka 
(Chęciny, Chmielnik, Małogoszcz, Bodzentyn). W ostatnim przypadku można postawić tezę, że leżą one w strefie wymywania wielkiego miasta. Kielce stanowią nie tylko atrakcyjny rynek zbytu, ale także rynek pracy, co powoduje, że bardziej wykształcona i przedsiębiorcza część ludności małych miast do nich emigruje (Kamińska 2004).

$\mathrm{Na}$ obszarach wiejskich dominowało 17 gmin, które łącznie skupiały 36,5\% ogólnej liczby zakładów funkcjonujących na obszarach wiejskich województwa i 29,6\% mieszkańców wsi badanego obszaru (ryc. 4). Wszystkie wymienione gminy leżą w pobliżu dużych ośrodków miejskich: siedem w pobliżu Kielc (Daleszyce, Morawica, Górno, Masłów, Zagnańsk, Miedziana Góra, Piekoszów), dwie w bezpośrednim sąsiedztwie Końskich (Stąporków, Radoszyce), po jednej w pobliżu Starachowic (Pawłów) i Ostrowca Świętokrzyskiego (Bodzechów), Włoszczowy (Krasocin), Buska-Zdroju (Stopnica) oraz Pińczowa.

W 46 gminach zlokalizowanych było po 201-500 MŚP. Łącznie obejmowały one 46,9\% zakładów zlokalizowanych na terenach wiejskich województwa oraz 48,5\% mieszkańców wsi badanego obszaru. Najmniejszą liczbę małych i średnich przedsiębiorstw (do 100) zanotowano w pięciu gminach: Bejsce, Zawichost, Suchedniów, Skalbmierz, Opatowiec. Skupiały one razem 1,4\% zakładów oraz 2,7\% mieszkańców. Gminy te leżą na peryferiach województwa, $\mathrm{z}$ dala od dużych miast i układów komunikacyjnych.

Ryc. 4. Małe i średnie przedsiębiorstwa na obszarach wiejskich woj. świętokrzyskiego w 2006 r.

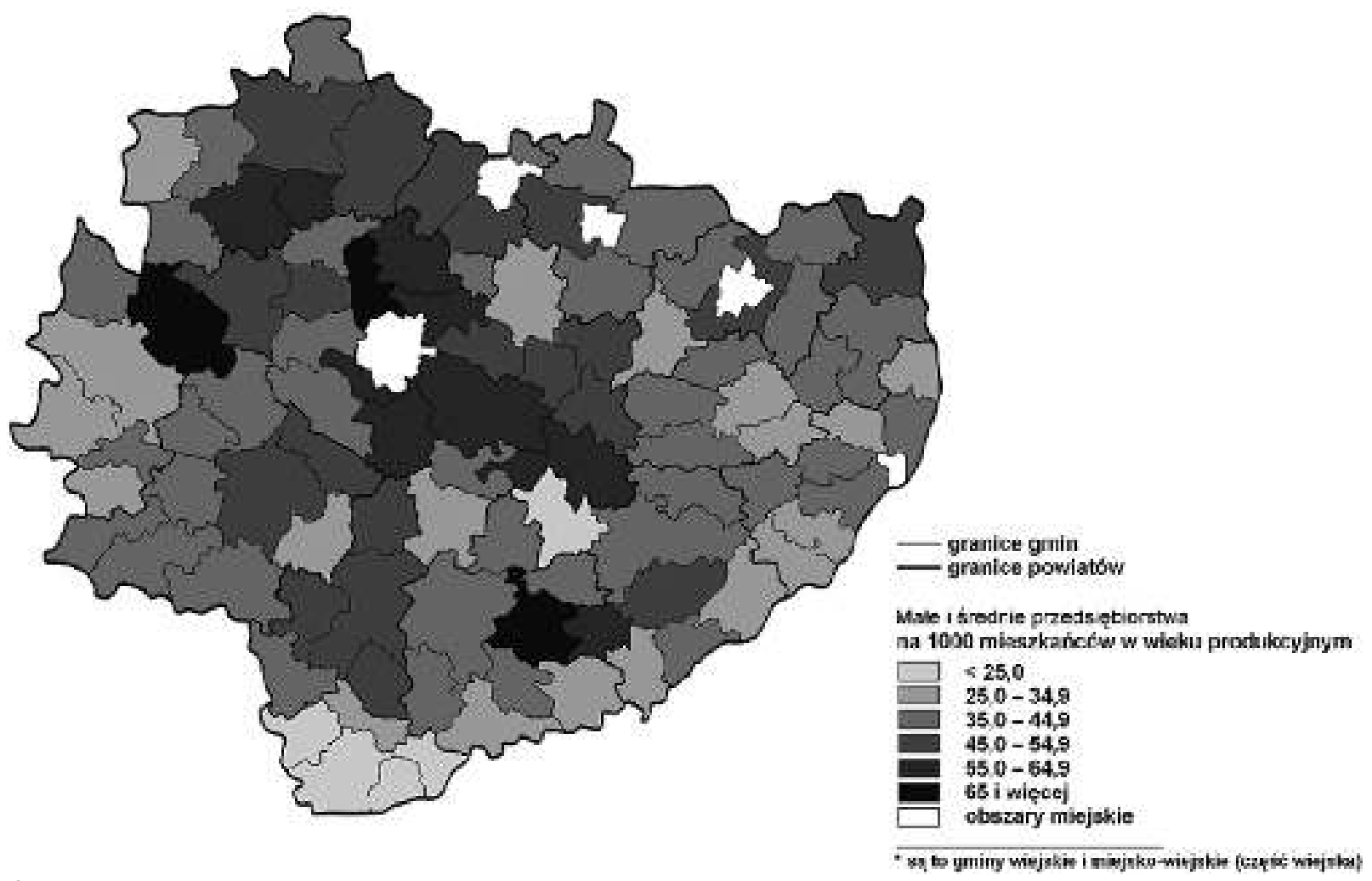

Źródło: opracowanie autora.

\section{Samorządowe instrumenty wspierania małych i średnich przedsiębiorstw}

Ustawy z 1990 r. o samorządzie gminnym i samorządzie terytorialnym stworzyły instrumenty umożliwiające czynne wspieranie rozwoju MŚP. Można je podzielić na instrumenty polityki budżetowej i instrumenty polityki cenowej (ryc. 5). 
Ryc. 5. Instrumenty gminy stymulujące rozwój pozarolniczej działalności gospodarczej

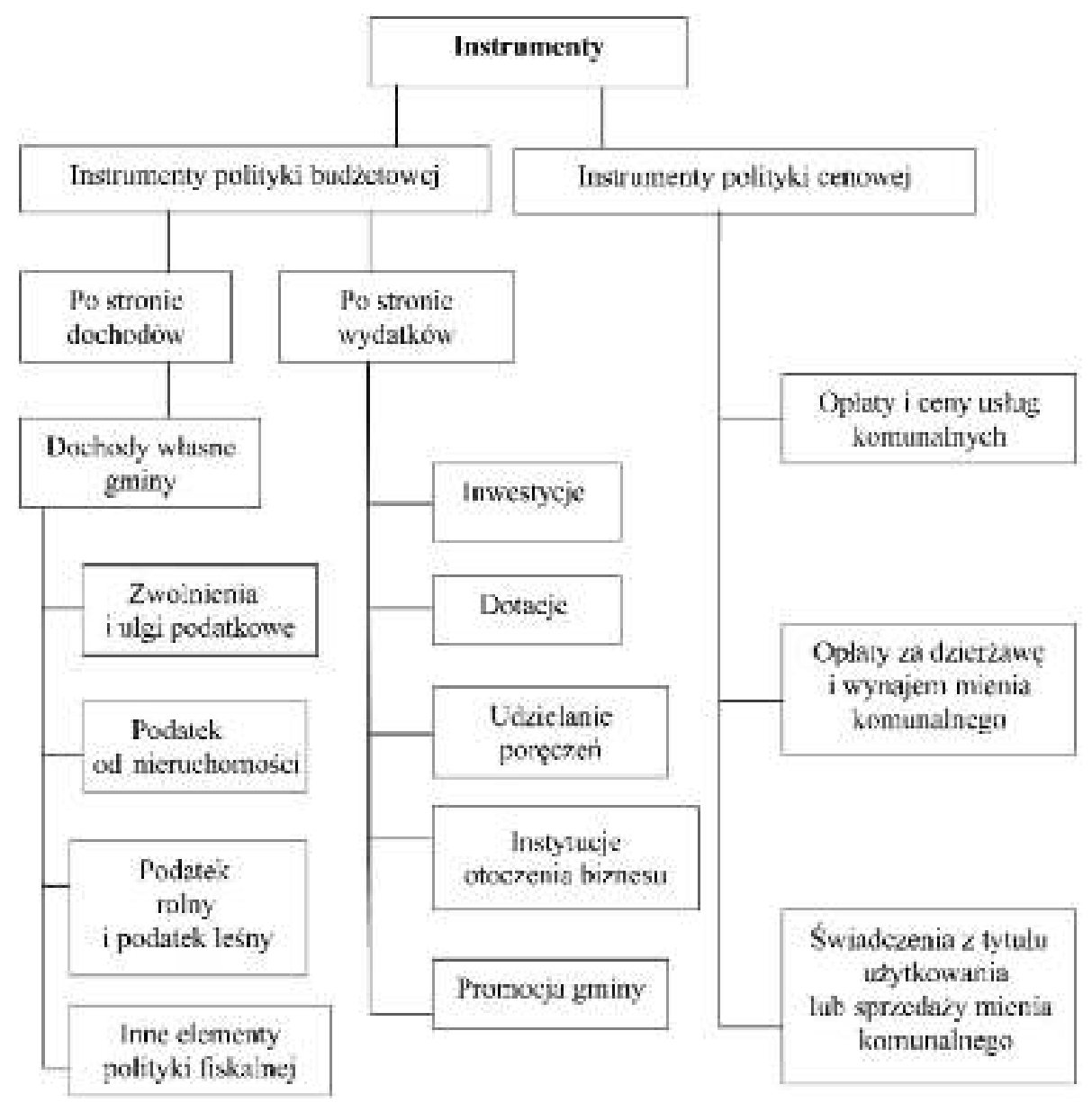

Opracowanie autora na podstawie: W. Kamińska 2006, op. cit.

\section{Wspieranie rozwoju sektora MŚP - wyniki badań ankietowych}

\section{Charakterystyka badanej próby}

Ankietę udało się przeprowadzić w 75 gminach, czyli w 73,5\% ogólnej liczby gmin w województwie. W tej grupie znajduje się 21 gmin miejsko-wiejskich oraz 54 gminy wiejskie (tab. 3, ryc. 6). W badaniu pominięto największe miasto województwa - Kielce. Było to działanie celowe, z badań wynika bowiem, że największe miasta (powyżej 200 tys. mieszkańców) prowadzą intensywną i zakrojoną na szeroką skalę politykę wspierania rozwoju MŚP. W niniejszej pracy skoncentrowano się głównie na obszarach wiejskich i mniejszych miastach.

Tab. 3. Liczba gmin objętych badaniem ankietowym

\begin{tabular}{|l|c|c|c|}
\hline \multirow{2}{*}{ Wyszczególnienie } & \multicolumn{2}{|c|}{ Liczba } & \multirow{2}{*}{ Powierzchnia (w km²) } \\
\cline { 2 - 4 } & gmin & ludności & \\
\hline Gminy miejsko-wiejskie & 21 & 171684 & 2931 \\
\hline Gminy wiejskie & 54 & 389203 & 5720 \\
\hline Razem & $\mathbf{7 5}$ & $\mathbf{1 7 1 6 8 4}$ & $\mathbf{8 6 5 1}$ \\
\hline
\end{tabular}

Źródło: zestawienie autora. 
Ryc. 6. Gminy objęte badaniem ankietowym

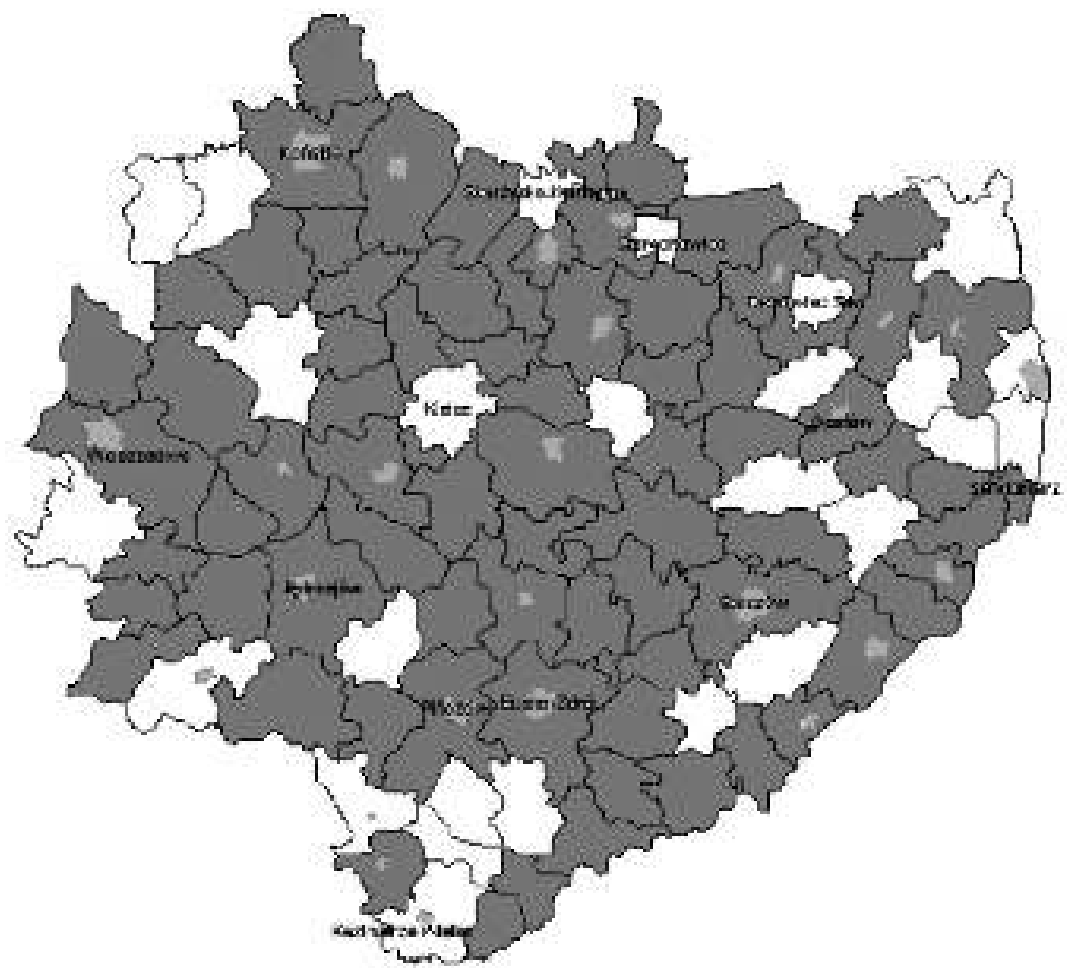

Źródło: opracowanie autora.

\section{Instrumenty dochodowe}

Wyniki badania ankietowego dowodzą, że stosowanie zróżnicowanych stawek podatkowych oraz zwolnień i ulg przyjmuje różne formy. $Z$ tab. 4 jednoznacznie wynika, że najczęściej władze samorządowe stosują obniżenia stawek podatkowych oraz zwolnienia i ulgi w podatku od środków transportu, a w dalszej kolejności - w podatku od nieruchomości i w podatku rolnym. Według prezentowanych badań $77 \%$ gmin zastosowało ulgi lub zwolnienia w podatku od środków transportu, $75,7 \%$ - w podatku od nieruchomości, a $68,9 \%$ - w podatku rolnym. Zdecydowanie rzadziej stosowane są zachęty $\mathrm{w}$ postaci ulg $\mathrm{w}$ podatku leśnym $(16,2 \%$ badanych gmin) i w karcie podatkowej $(4,1 \%)$.

Tab. 4. Stosowanie przez gminy woj. świętokrzyskiego stawek podatków niższych od maksymalnych (w \%)

\begin{tabular}{|l|c|c|c|}
\hline \multicolumn{1}{|c|}{ Wyszczególnienie } & Ogólem & $\begin{array}{c}\text { Gminy } \\
\text { miejsko-wiejskie }\end{array}$ & Gminy wiejskie \\
\hline $\begin{array}{l}\text { Podatek } \\
\text { od nieruchomości }\end{array}$ & 75,7 & 79,2 & 71,0 \\
\hline $\begin{array}{l}\text { Podatek } \\
\text { od środków transportu }\end{array}$ & 77,0 & 75,5 & 81,0 \\
\hline Podatek rolny & 68,9 & 71,4 & 67,9 \\
\hline Podatek leśny & 16,2 & 33,3 & 9,4 \\
\hline $\begin{array}{l}\text { Podatek } \\
\text { od spadków i darowizn }\end{array}$ & 8,1 & 14,3 & 5,7 \\
\hline $\begin{array}{l}\text { Podatek } \\
\text { od posiadania psów }\end{array}$ & 63,6 & 61,9 & 64,2 \\
\hline Karta podatkowa & 4,1 & 0 & 5,7 \\
\hline
\end{tabular}

Źródło: wyliczenia autora na podstawie badań. 
Gminy miejsko-wiejskie najczęściej stosują niższe od maksymalnej stawki podatku od nieruchomości $(79,2 \%)$, a następnie zachęty w postaci ulg w podatku od środków transportu $(75,5 \%)$ i w podatku rolnym (71,4\%) (tab. 4, ryc. 7, 8 i 9). Gminy wiejskie główny instrument wspierania rozwoju MŚP widzą w stosowaniu niższych stawek oraz w ulgach i zwolnieniach w podatku od środków transportu (81\%), a dopiero w dalszej kolejności - w podatku od nieruchomości (71\%) i podatku rolnym $(67,9 \%)$.

Na podstawie analizy można stwierdzić, że im gmina mniejsza (pod względem liczby mieszkańców), tym częściej stosuje niższe od maksymalnych stawki podatków od nieruchomości.

Na pytanie, czy polityka gminy w zakresie ulg i zwolnień podatkowych dla przedsiębiorców jest stabilna, 86,7\% gmin odpowiedziało twierdząco, przy czym 26,7\% odpowiedziało „tak”, a 37,7\% ,raczej tak”. Zaledwie 13,3\% odpowiedziało przecząco (,raczej nie” 8\%, „nie” $5,3 \%)(\operatorname{tab} .5)$.

Ryc. 7. Gminy stosujące stawki podatku od nieruchomości niższe niż maksymalne

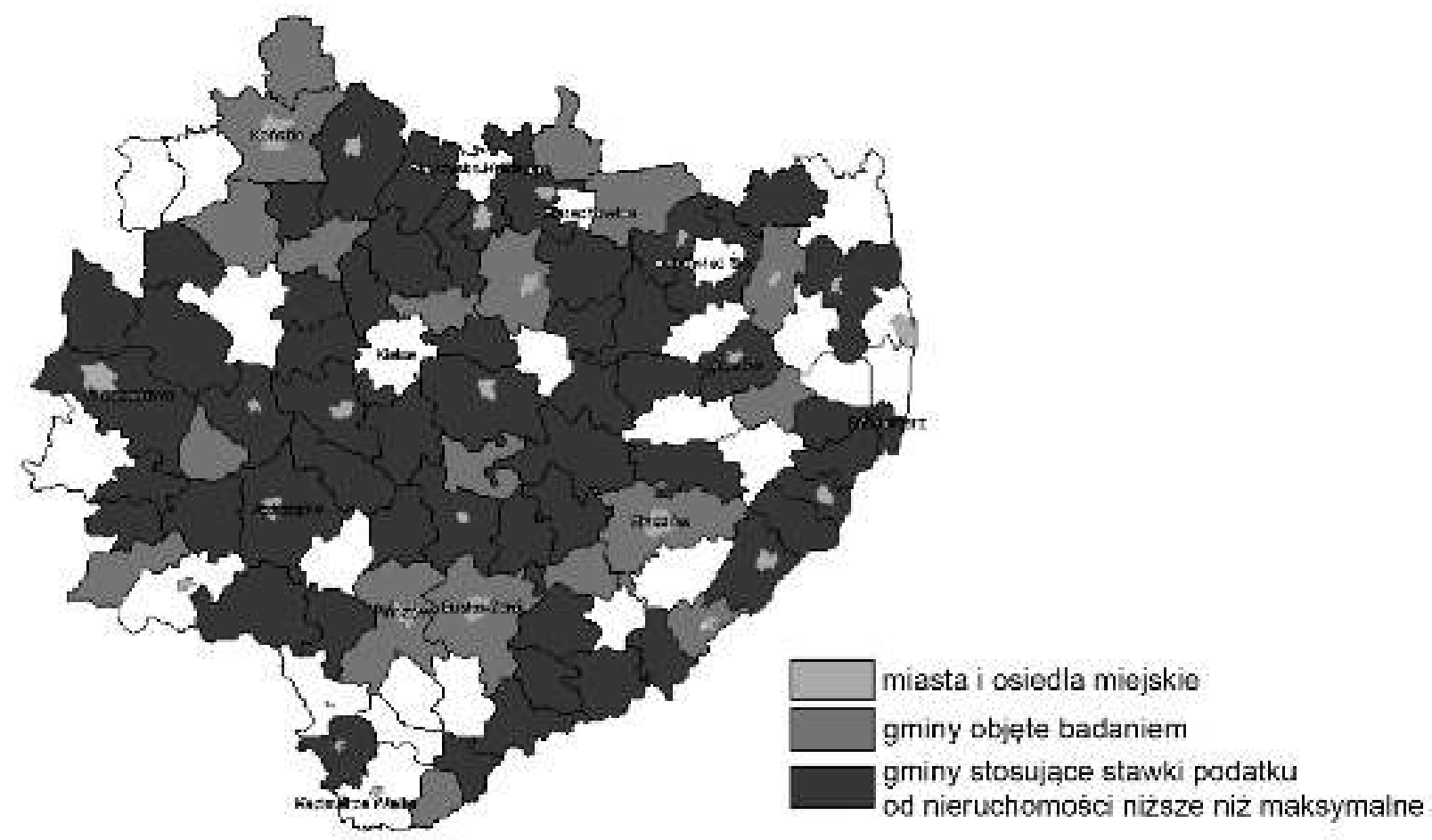

Zródło: opracowanie autora.

Tab. 5. Odpowiedź gminy na pytanie, czy polityka w zakresie ulg i zwolnień podatkowych jest dla przedsiębiorców stabilna

\begin{tabular}{|c|c|c|c|c|}
\hline \multirow{2}{*}{ Wyszczególnienie } & \multicolumn{4}{|c|}{ Odpowiedź } \\
\cline { 2 - 5 } & tak & raczej tak & raczej nie & nie \\
\hline $\begin{array}{l}\text { Gminy miejsko- } \\
\text {-wiejskie }\end{array}$ & 4 & 17 & 0 & 0 \\
\hline Gminy wiejskie & 16 & 28 & 6 & 4 \\
\hline Razem & $\mathbf{2 0}$ & $\mathbf{4 5}$ & $\mathbf{6}$ & $\mathbf{4}$ \\
\hline
\end{tabular}

Źródło: opracowanie autora. 
Ryc. 8. Gminy stosujące niższe niż maksymalne stawki podatku od środków transportu

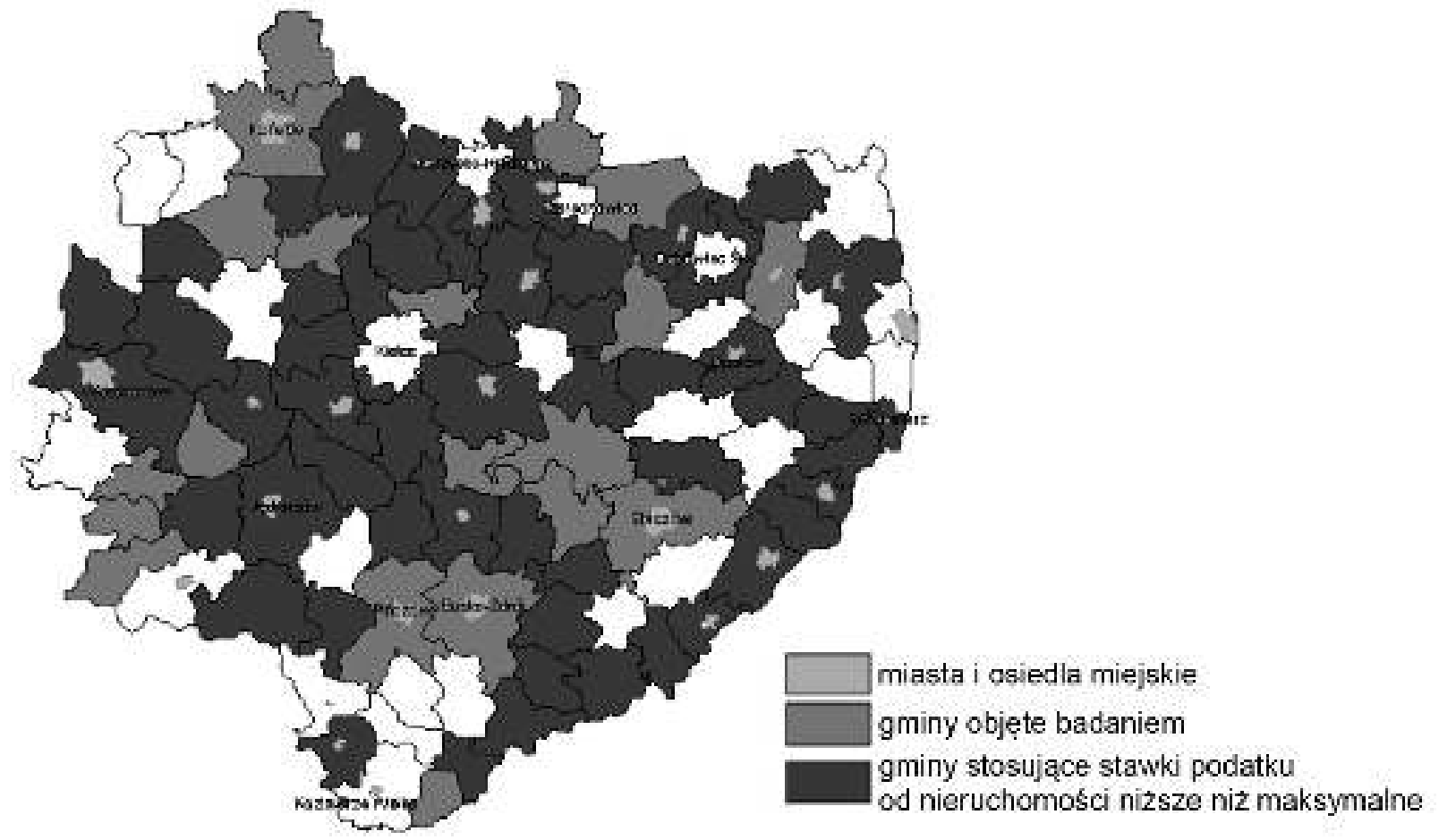

Źródło: opracowanie autora.

Ryc. 9. Gminy stosujące niższe niż maksymalne stawki podatku rolnego

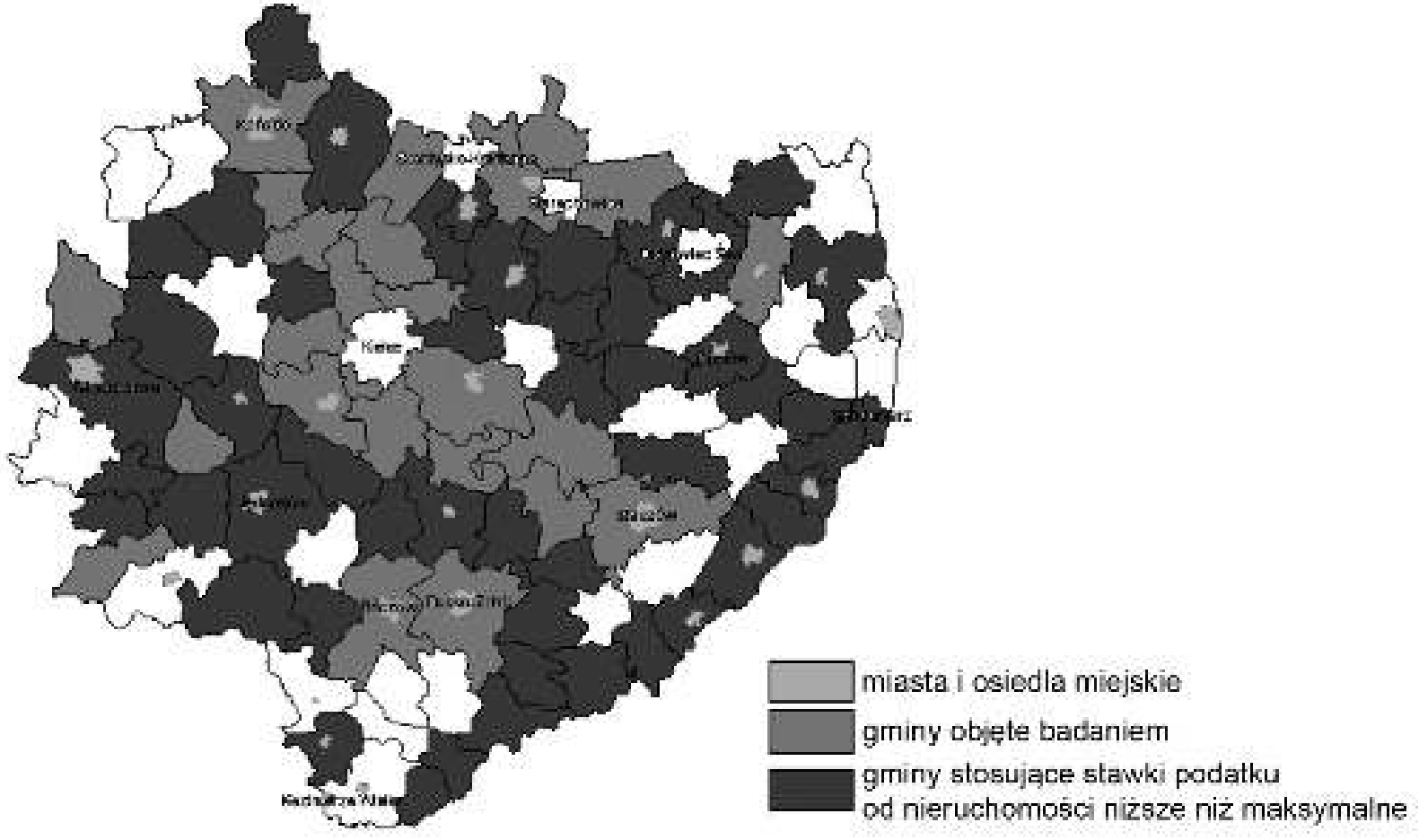

Źródło: opracowanie autora.

\section{Instrumenty wydatkowe - obligacje i inwestycje}

Pierwszą badaną w tym zakresie kwestią były emisja obligacji oraz gotowość gmin do zaciągnięcia długoterminowych kredytów inwestycyjnych. Spośród badanych gmin tylko trzy podjęły decyzję o emisji obligacji (Bejsce, Piekoszów i Osiek; ryc. 10). Wszystkie wymienione gminy podjęły taką decyzję w latach 2003-2005. 
Ryc. 10. Gminy, które podjęły decyzję o emisji obligacji

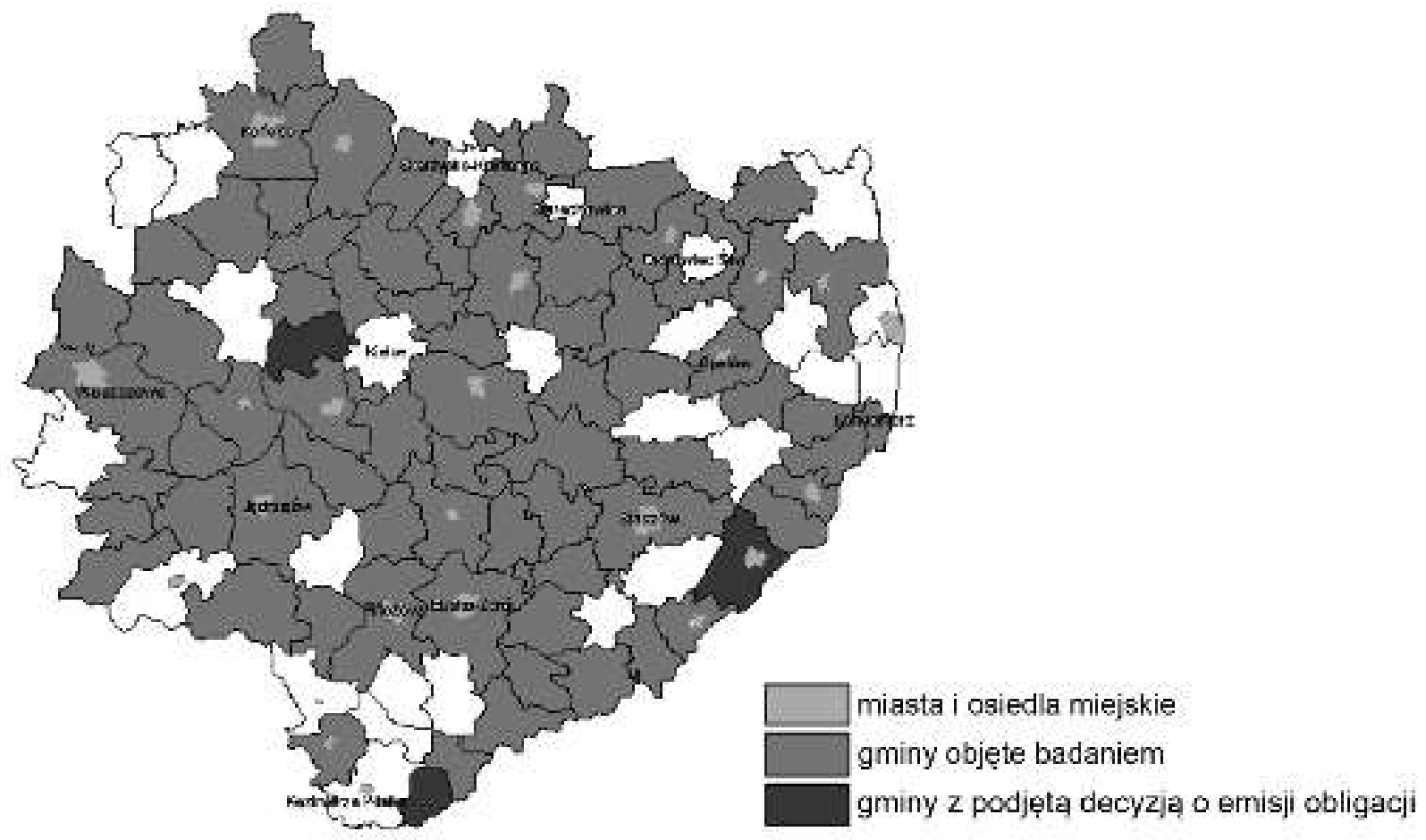

Źródło: opracowanie autora.

$61,3 \%$ badanych gmin zaciągnęło długoterminowe kredyty inwestycyjne, zdecydowana większość z nich w latach 2002-2005. Spośród tych gmin 15 - gminy miejsko-wiejskie (71,4\% ogółu badanych gmin miejsko-wiejskich), a 31 - gminy wiejskie (58,5\% ogółu badanych gmin wiejskich). Oznacza to, że na zaciąganie długoterminowych kredytów inwestycyjnych częściej decydują się gminy miejsko-wiejskie (tab. 6, ryc. 11).

Tab. 6. Liczba gmin, w których podjęto decyzje w sprawie emisji obligacji i zaciągania długoterminowych kredytów inwestycyjnych

\begin{tabular}{|l|c|c|c|}
\hline \multirow{2}{*}{ Wyszczególnienie } & \multicolumn{3}{|c|}{ Liczba gmin } \\
\cline { 2 - 4 } & ogólem & miejsko-wiejskch & wiejskich \\
\hline Emisja obligacji & 3 & 2 & 1 \\
\hline $\begin{array}{l}\text { Długoterminowe } \\
\text { kredyty inwestycyjne }\end{array}$ & 46 & 15 & 31 \\
\hline
\end{tabular}

Źródło: opracowanie autora.

Więcej niż połowa badanych gmin (66\%) ma opracowaną strategię inwestycyjną na najbliższe 5 lat. Wśród tej grupy jest 36 gmin wiejskich oraz 13 gmin miejsko-wiejskich. Spośród najczęściej realizowanych inwestycji gminy wymieniają inwestycje kanalizacyjne i wodociągowe oraz budowę oczyszczalni ścieków. 1/3 gmin wskazuje inwestycje drogowe, a 16\% wymienia inwestycje energetyczne. 10\% spośród badanych gmin rozwijało sieć telefoniczną.

Przeprowadzone badania wykazały również, że 40 (54\%) gmin planuje rozpoczęcie inwestycji, które wpłyną na rozwój sektora MŚP. W tej grupie jest 30 gmin wiejskich $(71,4 \%$ ogólnej liczby badanych gmin wiejskich) oraz 10 gmin miejsko-wiejskich (47,6\% ogólnej liczby badanych gmin miejsko-wiejskich). Można więc stwierdzić, że gminy wiejskie częściej planują tego rodzaju inwestycje aniżeli gminy miejsko-wiejskie. Wśród planowanych inwestycji przeważają inwestycje wodno-kanalizacyjne oraz inwestycje drogowe. 
Ryc. 11. Gminy, w których podjęto decyzję o zaciągnięciu długoterminowych kredytów inwestycyjnych

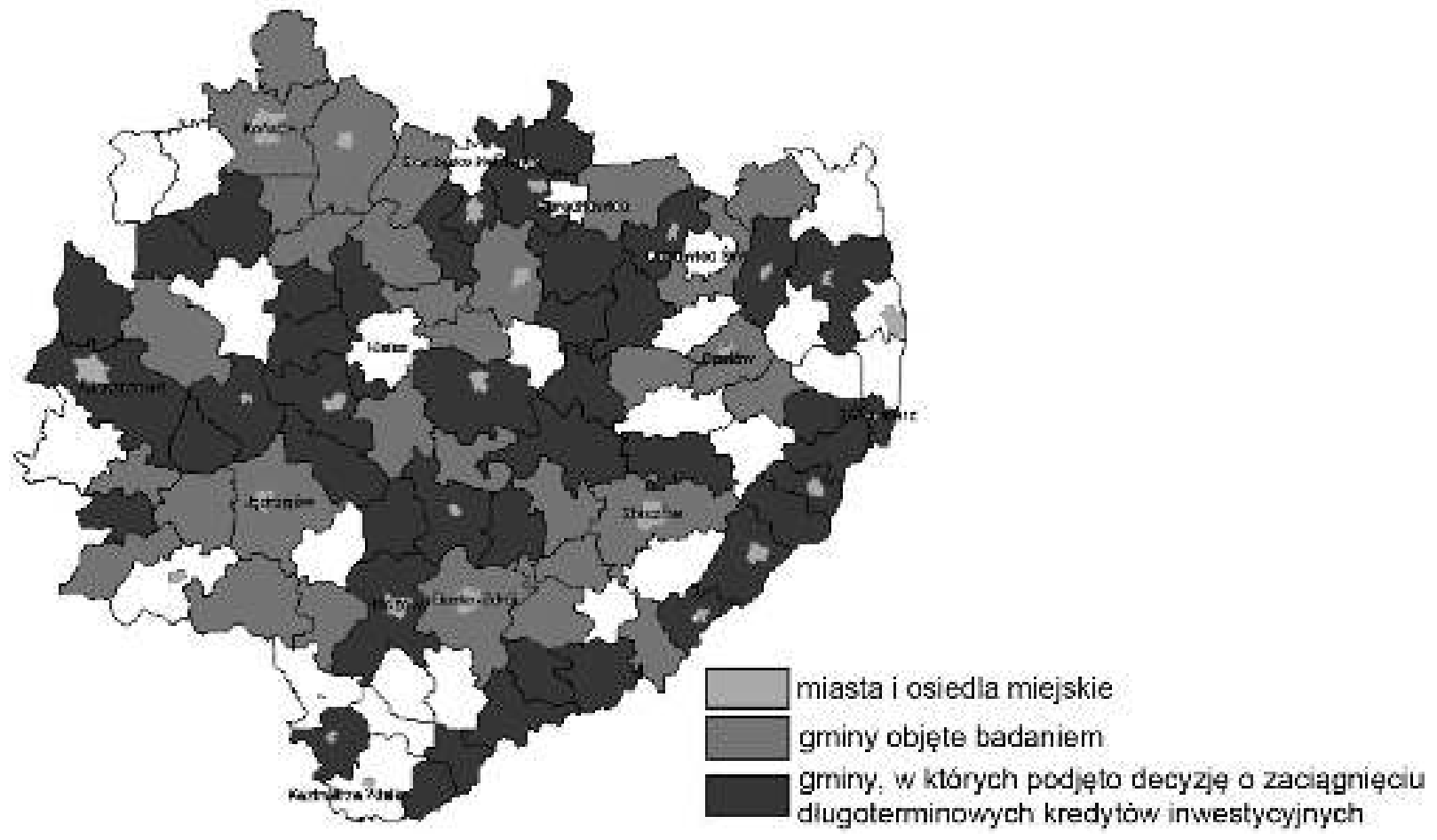

Żródło: opracowanie autora.

\section{Finansowanie rozwoju sektora MŚP}

W badaniach poruszono problem finansowania przez gminy różnego rodzaju przedsięwzięć i instytucji, które służą rozwojowi MŚP. Niestety, okazało się, że ten instrument w woj. świętokrzyskim jest stosowany rzadko (tab. 7). W 2003 r. tylko pięć gmin dofinansowało lub współfinansowało przedsięwzięcia realizowane z podmiotami gospodarczymi, w których udział miała gmina. Były to cztery gminy wiejskie (Brody, Bejsce, Radoszyce, Słupia Konecka) i jedna gmina miejsko-wiejska (Suchedniów).

Tab. 7. Liczba gmin stosujących wybrane instrumenty finansowego wspierania sektora MŚP w woj. świętokrzyskim w latach 2003 i 2006

\begin{tabular}{|l|c|c|c|c|c|c|}
\hline \multirow{2}{*}{\multicolumn{1}{c|}{ Instrument }} & \multicolumn{5}{c|}{ Liczba gmin } \\
\cline { 2 - 7 } & ogółem & $\begin{array}{c}\text { miejsko- } \\
\text {-wiejskich }\end{array}$ & miejskich & ogółem & $\begin{array}{c}\text { miejsko- } \\
\text {-wiejskich }\end{array}$ & miejskich \\
\cline { 2 - 7 } & \multicolumn{3}{|c|}{$\mathbf{2 0 0 3}$} & \multicolumn{2}{c|}{$\mathbf{2 0 0 6}$} \\
\hline $\begin{array}{l}\text { Dofinansowanie (współfinansowanie) } \\
\text { przedsięwzięć realizowanych z podmiotami } \\
\text { gospodarczymi, w których udział ma gmina }\end{array}$ & 5 & 1 & 4 & 7 & 2 & 5 \\
\hline $\begin{array}{l}\text { Dofinansowanie (współfinansowanie) } \\
\text { przedsięwzięć realizowanych przez innych } \\
\text { lokalnych przedsiębiorców }\end{array}$ & 0 & 0 & 1 & 1 & 0 & 1 \\
\hline $\begin{array}{l}\text { Dotowanie (współfinansowanie) } \\
\text { organizacji wspierających rozwój MŚP, } \\
\text { w których udział ma gmina }\end{array}$ & 0 & 0 & 0 & 0 & 0 & 0 \\
\hline $\begin{array}{l}\text { Dotowanie (współfinansowanie) innych } \\
\text { organizacji wspierających rozwój MŚ́ }\end{array}$ & 2 & 0 & 2 & 2 & 0 & 2 \\
\hline
\end{tabular}

Źródło: opracowanie autora. 
Ani jedna gmina nie dofinansowała przedsięwzięć realizowanych przez innych lokalnych przedsiębiorców ani nie dotowała organizacji wspierających rozwój MŚP, w których udział miała gmina. Tylko dwie gminy - Waśniów i Brody - dotowały inne organizacje wspierające rozwój sektora MŚP.

W 2006 r. sytuacja prawie się nie zmieniła i wskazane wyżej instrumenty były stosowane w stopniu znikomym. Pierwszy z nich zastosowało siedem gmin (obok wymienionych wcześniej, także Waśniów i Połaniec). Drugi instrument zastosowała tylko gmina Radoszyce, trzeciego nie włączyła do swojego instrumentarium żadna gmina, czwarty - dwie gminy, które wykorzystywały już ten sposób wspierania rozwoju MŚP w 2003 r.

\section{Udzielanie gwarancji i poręczeń kredytowych}

Udzielanie gwarancji i poręczeń kredytowych jest niezwykle ważnym instrumentem wspierania rozwoju sektora MŚP. Jednak, jak wykazały badania ankietowe, gminy woj. świętokrzyskiego prawie wcale nie korzystają z tej zachęty dla przedsiębiorców. Zaledwie 11 gmin wykorzystało ten instrument $\mathrm{w}$ polityce wspierania rozwoju przedsiębiorczości na swoim terenie. W tej grupie znalazło się dziewięć gmin wiejskich (Bejsce, Bogoria, Krasocin, Łagów, Łubnice, Nowa Słupia, Pierzchnica, Samborzec, Waśniów) i dwie gminy miejsko-wiejskie (Chmielnik, Suchedniów).

\section{Szkolenia i doradztwo}

Spośród badanych gmin 35 (46,7\%) organizuje szkolenia podnoszące kwalifikacje miejscowej ludności (lub pomaga w ich organizacji). Tego typu działania częściej podejmują gminy wiejskie - na taką pomoc we wspieraniu rozwoju sektora MŚP zdecydowało się prawie 50\% ankietowanych gmin wiejskich (tab. 8). W grupie gmin stosujących ten instrument znalazło się dziewięć gmin miejsko-wiejskich (42,8\% ogólnej liczby tego typu gmin). Oznacza to, że władze gmin wiejskich zdają sobie sprawę, że na ich terenie jest ograniczona możliwość podnoszenia kwalifikacji miejscowej ludności i wychodzą naprzeciw zapotrzebowaniu.

Znacznie rzadziej gminy decydują się na finansowanie tego typu przedsięwzięć; tylko dziewięć z nich potwierdziło swoją aktywność w tym zakresie. W tej grupie było osiem gmin wiejskich (Brody, Krasocin, Nagłowice, Nowy Korczyn, Skarżysko Kościelne, Stopnica, Wodzisław i Waśniów) i jedna miejsko-wiejska (Pińczów).

Tab. 8. Organizacja szkoleń i doradztwa jako instrumentu wspierania rozwoju MŚP w badanych gminach woj. świętokrzyskiego

\begin{tabular}{|l|c|c|c|}
\hline \multicolumn{1}{|c|}{ Wyszczególnienie } & \multicolumn{3}{c|}{ Liczba gmin } \\
\cline { 2 - 4 } & ogółem & miejsko-wiejskich & wiejskich \\
\hline $\begin{array}{l}\text { Organizacja szkoleń podnoszących } \\
\text { kwalifikacje miejscowej ludności }\end{array}$ & 35 & 9 & 26 \\
\hline $\begin{array}{l}\text { Finansowanie szkoleń podnoszácych } \\
\text { kwalifikacje miejscowej ludności }\end{array}$ & 9 & 1 & 8 \\
\hline $\begin{array}{l}\text { Organizacja szkoleń ułatwiających } \\
\text { prowadzenie firmy }\end{array}$ & 8 & 2 & 6 \\
\hline $\begin{array}{l}\text { Finansowanie szkoleń } \\
\text { ułatwiających prowadzenie firmy }\end{array}$ & 2 & 1 & 1 \\
\hline $\begin{array}{l}\text { Finansowanie ośrodków } \\
\text { prowadzących doradztwo dla firm }\end{array}$ & 1 & 0 & 1 \\
\hline
\end{tabular}

Źródło: opracowanie autora. 
Tylko osiem gmin zdecydowało się na organizację szkoleń ułatwiających prowadzenie firmy. Tę grupę reprezentuje sześć gmin wiejskich (Baćkowice, Łagów, Mniów, Pierzchnica, Raków, Słupia Konecka) i dwie gminy miejsko-wiejskie (Bodzentyn, Chęciny).

Niezwykle rzadko gminy jako instrument wspierający rozwój sektora MŚP na swoich terenach wykorzystują finansowanie szkoleń ułatwiających prowadzenie firmy. Jak wynika z przeprowadzonych badań, w woj. świętokrzyskim tylko dwie gminy (Skarżysko Kościelne i Suchedniów) zastosowały analizowany instrument.

Jeszcze rzadziej gminy uczestniczą w finansowaniu ośrodków prowadzących doradztwo dla firm. Tylko gmina Łagów podjęła inwestycję zachęcającą do prowadzenia działalności gospodarczej.

\section{Instytucje otoczenia biznesu}

Tworzenie instytucji otoczenia biznesu jest instrumentem stosowanym w województwie świętokrzyskim niezwykle rzadko. Tylko 2 gminy: Chęciny i Kije zadeklarowały, że uczestniczą w tworzeniu inkubatora przedsiębiorczości (tab. 9). Jedynie gmina Wąchock zdecydowała się na działania zmierzające do utworzenia agencji rozwoju lokalnego i agencji inicjatyw lokalnych. 3 gminy: Suchedniów, Chęciny i Raków uczestniczyły w tworzeniu ośrodków doradczo-szkoleniowych, a stworzenie funduszu poręczeniowo-kredytowego zadeklarowała gmina Chęciny. Oznacza to, że najbardziej aktywną gminą w zakresie tworzenia instytucji otoczenia biznesu okazała się gmina Chęciny.

Tab. 9. Liczba gmin uczestniczących w tworzeniu instytucji otoczenia biznesu w woj. świętokrzyskim

\begin{tabular}{|l|c|c|c|}
\hline \multicolumn{1}{|c|}{ Wyszczególnienie } & \multicolumn{3}{c|}{ Liczba gmin } \\
\cline { 2 - 4 } & ogólem & miejsko-wiejskich & wiejskich \\
\hline $\begin{array}{l}\text { Inkubatory przedsiębiorczości } \\
\text { i centra wspierania biznesu }\end{array}$ & 2 & 1 & 1 \\
\hline $\begin{array}{l}\text { Agencje rozwoju lokalnego } \\
\text { i agencje inicjatyw lokalnych }\end{array}$ & 1 & 1 & 0 \\
\hline Ośrodki doradczo-szkoleniowe & 3 & 2 & 1 \\
\hline Fundusze poręczeniowo-kredytowe & 2 & 1 & 1 \\
\hline
\end{tabular}

Źródło: opracowanie autora.

\section{Promocja i strategia wspierania rozwoju sektora MŚP}

$\mathrm{Na}$ pytanie, czy gmina ma opracowaną strategię rozwoju, pozytywnie odpowiedziało $76 \%$ respondentów. W tej grupie znalazło się 39 gmin wiejskich i 17 gmin miejsko-wiejskich. W większości strategii rozwoju sformułowano cele odnoszące się do rozwoju przedsiębiorczości i lokalnych firm. Najczęściej wymienianym celem było tworzenie instytucji otoczenia biznesu, głównie inkubatorów przedsiębiorczości. Działalność inkubatorów przedsiębiorczości w innych krajach potwierdza ich znaczenie. Stanowią one instrument wspomagający tworzenie nowych miejsc pracy i pomoc w rozwijaniu różnych rodzajów działalności.

Na pytanie, czy gmina ma przygotowany specjalny program pomocy dla małych i średnich przedsiębiorstw, zaledwie trzy (Pińczów, Piekoszów i Morawica) odpowiedziały twierdząco.

Tylko dwie gminy (Chęciny i Suchedniów) zadeklarowały, że mają opracowany program wspierania lokalnych produktów, i tylko 10 gmin utworzyło w swoich urzędach jednostki do spraw promocji przedsiębiorczości, a 5 do obsługi inwestorów zagranicznych. 


\section{Wnioski}

Wyniki analizy pozwalają na następujące konkluzje.

Władze lokalne w woj. świętokrzyskim widzą potrzebę i konieczność wspierania rozwoju sektora MŚP, jednak struktura stosowanych instrumentów nie jest właściwa; najczęściej wykorzystuje się instrumenty proste: ulgi podatkowe, szkolenia i inwestycje (które należą do zadań własnych gminy). Instrumenty te mają charakter pośredni, więc ich skuteczność jest ograniczona. Lepsze są instrumenty bezpośrednie, które stwarzają warunki do podejmowania działalności gospodarczej w gminie, np. miejscowy plan zagospodarowania przestrzennego, strategiczny program rozwoju, fundusze kapitałowe.

Władze gminne w woj. świętokrzyskim zmierzają do tworzenia instytucji otoczenia biznesu (inkubatory przedsiębiorczości, agencje rozwoju lokalnego), są to jednak działania powolne i w najbliższym okresie nie należy się spodziewać poprawy tej sytuacji.

Społeczność lokalna i władze gminne w procesie wspierania sektora MŚP powinny dążyć do wykorzystywania w większym stopniu prywatnego kapitału. Mogą współtworzyć organizacje promujące gminę lub udzielające wzajemnych poręczeń kredytowych. Istotne jest organizowanie targów, wystaw i konkursów promujących lokalne produkty.

Działania na rzecz wspierania rozwoju MŚP prowadzą przede wszystkim gminy miejskie. Polityka gmin wiejskich w tym zakresie jest ograniczona, przede wszystkim ze względu na skromne środki finansowe. Nie bez znaczenia jest także brak orientacji urzędników samorządowych w kwestii dostępnego instrumentarium umożliwiającego rozwój własnego regionu.

Optymistyczny jest fakt, że wszystkie ankietowane gminy zadeklarowały intensywne wspieranie w przyszłości małych i średnich przedsiębiorstw oraz wykorzystywanie większej liczby instrumentów dostępnych w granicach prawa.

\section{Literatura}

1. Dębski J., 2002, Lokalne bieguny wzrostu w Polsce na przełomie XX i XXI wieku, Wyższa Szkoła Finansów i Zarządzania w Białymstoku, Białystok.

2. Dolata M., 2006, Małe i średnie przedsiębiorstwa w gospodarce województwa lubuskiego, Bogucki Wydawnictwo Naukowe, Poznań.

3. Hausner J., Kudłacz T., Szlachta J., 1995, Instytucjonalne warunki restrukturyzacji regionalnej Polski, Studia KPZK PAN, Warszawa.

4. Kamińska W., 2004, Warunki rozwoju małych przedsiębiorstw w województwie świętokrzyskim [w:] Alternatywne źródta dochodów gospodarstw rolnych, IGAŚ, Kielce.

5. Kamińska W., 2006, Pozarolnicza indywidualna działalność gospodarcza $w$ Polsce $w$ latach 1988-2003, IGiPZ PAN, Warszawa.

6. Schumacher E.F., 1981, Małe jest piękne, PIW, Warszawa.

7. Swaniewicz P., Dziemianowicz W., 1998, Atrakcyjność inwestycyjna miast, Instytut Badań nad Gospodarką Rynkową, Warszawa.

8. The European Observatory for SMEs Sixth Report, 2005, European Commission.

9. Zioło Z., 1994, Struktura funkcjonalna i układ przestrzenny centrów regionalnych Polski Poludniowo-Wschodniej [w:] Problemy transformacji struktur regionalnych w procesie przechodzenia do gospodarki rynkowej, J. Kitowski i Z. Zioło (red.), Sekcja Gospodarki Przestrzennej Komisji Nauk Ekonomicznych PAN Oddz. w Krakowie, Wydział Ekonomiczny UMCS Filia w Rzeszowie, pod patronatem Komitetu Przestrzennego Zagospodarowania Kraju PAN, Kraków-Rzeszów-Warszawa. 


\section{The Ways of Supporting Development of Small and Medium Enterprises in Swietokrzyskie Province - Results of Research Questionnaires}

The purpose of this article is to show the results of research questionnaires concerned the ways of supporting development of small and medium enterprises (SME) in Swietokrzyskie Province. These results show that the stimulation of local and regional economy through the development of SME is effective way to reduction the effects of recession. Therefore local authorities should influence the improvement of the attractiveness of localization of their area. The efforts to economic development is their responsibility and it needs to initiate and favor the entrepreneurship.

There are almost 42,000 SMEs in Świętokrzyskie and 150,000 persons $(77,7 \%)$ are employed by them. More than $60 \%$ of these entities operate in the cities. The entrepreneurial indicators that illustrate the number of SME for 1000 citizens are among the lowest in the country. The research shows local authorities in Świętokrzyskie are moderate interested in the development of SME. They usually use the simplest instruments - the tax reliefs or trainings. But the range of instruments supported SME is worth extending. So it is possible to use modified instruments tried in other countries, for example prime d'aménagement du territoire (PAT), contract procedures or employee mobility. 